\title{
Poverty, Deprivation, and Social Exclusion as Source of Violent Conflict: Case Study of West Papua Post-New Order Era
}

\author{
Made Fitri Maya Padmi* \\ Universitas 17 Agustus 1945 Jakarta \\ fitrimayapadmi02@gmail.com
}

\begin{abstract}
Abstrak
Tulisan ini akan membahas mengenai kompleksitas hubungan antara kemiskinan dan konflik kekerasan. Konflik kekerasan selalu mengakibatkan kerugian dalam hal nyawa manusia, ekonomi dan kehidupan social, dan juga merupakan sumber utama dari kemiskinan dan keterbelakangan pembangunan. Tulisan ini juga membahas tentang keterkaitan antara keterbatasan sumber daya, keterkucilan dalam kehidupan social dan kemiskinan akan meningkatkan rasa ketidaksetaraan yang dapat menimbulkan kekerasan. Kemiskinan membuat suatu masyarakat menjadi lebih rentan terhadap provokasi-provokasi untuk melakukan tindak kekerasan; kerentanan ini disebabkan oleh rasa ketidakadilan dan bahwa kekerasan dapat memberikan solusi yang lebih terhadap permasalahan yang ada. Tulisan ini mengambil contoh kasus di Papua Barat dimana kondisi kemiskinan dan keterkucilan social saling berkaitan. Dan dalam konflik ini dapat terlihat bahwa kekerasan struktural dapat menghasilkan dan melanggengkan kemiskinan.
\end{abstract}

Kata kunci: Deprivasi, Kemiskinan, Keterkucilan Sosial, Konflik Kekerasan, Papua.

\begin{abstract}
This article discuses about the complexity of causal relation between poverty and violent conflict. Violent conflicts have huge human, economic, and social costs and are a major cause of poverty and underdevelopment. The article suggests that the coupling between deprivation, social exclusion and poverty increases the significance of inequality and may contribute to violence. Poverty conditions make the victims more vulnerable to being provoked into committing violent actions; this vulnerability is due to the grievance of deprivation and the incentives that the violence offers given the misery of the present

condition. This paper takes the West Papua conflict as an example in which the conditions of poverty and social exclusion are entrenched. The violent conflict in West Papua, Indonesia has shown the pattern that structural violence can produce and sustain poverty.
\end{abstract}

Keywords: Deprivation, Papua, Poverty, Social Exclusion, Violent Conflict

\footnotetext{
${ }^{*}$ Department of International Relations, Faculty of Social and Political Science, Universitas 17 Agustus 1945 Jakarta Jl. Sunter Permai Raya Tanjung Priok Jakarta Utara 14350, (021) 64715666.
} 


\section{Introduction}

The Post-Cold War era marked the merger of development and security. When examining the link between poverty and conflict, there was traditionally perceived a causal relation that goes in only one direction, with conflict as the cause of poverty. However, the opposite is true as well: underdevelopment could cause insecurity for the surrounding environment and thus lead to conflict. In other words, there is also a causal relation of poverty as the cause of conflict.

This paper tries to explain the causal relation of poverty as the cause of violent conflict. This paper examines how poverty can lead the state and society to enact structural violence. The deprivation of the poor cannot, and their frustrations at being unable to meet the standard of living set by the society and at facing social exclusion from socioeconomic aspects, in the end will generate grievances due to the injustice. There are some debates against the concept that poverty can directly lead to violence. However, these debates rely on the assumption that impoverished people are functioning in the same way as financially stable people. This is problematic and weakens the debates, as the capacity of people to handle the grievances and frustrations of socioeconomic deprivation are different. Accumulation of grievances and mobilization to conduct violent actions to achieve improvement in quality of living are more likely to lead to the emergence of a wider violent movement. Poor people are more prone to join the violent movement due to a lack of alternative solutions, the high incentive of economic improvement, and as they have less to lose. This paper takes the West Papua conflict as an example in which the conditions of poverty and social exclusion are embedded.

\section{Poverty as a Source of Violence}

The meaning of poverty has been heavily debated. Is poverty about low income, social problems or malnutrition? Poverty can have many different meanings, and these meanings can contest with each other (Spicker, 2007). The World Summit for Social Development, Copenhagen in 1995 stated that the definition of poverty... 
has various manifestations, including lack of income and productive resources to ensure sustainable livelihoods; hunger and malnutrition; ill-heath; limited or lack of access to education or other basic services; increased morbidity and mortality from illness; homelessness and inadequate housing; unsafe environments and social discrimination and exclusion (UN, 1995).

The definition from the World Summit for Social Development showed that poverty is about not only money and income, but also socioeconomic problems. Poverty is about material needs, economic condition and social interaction. Spicker (2007) explained that poverty is related to the inability of people to fulfil their basic needs (i.e. a lack of income and resources) and social relations (e.g. social rights, exclusion and participation in society).

Poverty has many causes. Some scholars argue that the causes are natural, and some argue that the causes are created or recreated within the dynamic of social order. The argument for natural causes lies on the premise that people are the determining actors of their own fortune or misfortune based on their choices and actions (Alcock, 2006). The argument that poverty is created or at least recreated by structural factors asserts the importance of social conditions and forces and opportunities (or lack thereof) capable of determining people's lifecourse. This structural argument is closely link to the political policies and social perceptions about poverty and poor people. While the argument of poverty as a product of people's choices has been criticized as generalizing people as passive actors who cannot or do not want to upgrade their standard of living, the definition of poverty as a structural product gives more comprehensive analysis on the causes of poverty. The latter thus provides a better tool to explain how poverty can lead to dissatisfaction, grievances and eventually violence.

Poverty caused by a structural system is related to how the government addresses the issue of poverty. The condition of poverty relies on the success or failure of government policy to create and implement social and economic programmes to eradicate poverty (MacGregor, 1981). Political action is crucial in determining the political and social lives of citizens, including those of the poor. 
Poverty is produced by the economic system, whether market-based or capitalist, implemented by the government (Alcock, 2006; Novak, 1988). In market-based systems, political actions have no or limited power to control economic flow for their own people (Alcock, 2006). National politicians cannot act freely to influence all economic pressures, and as a result, uncontrolled economic forces can raise the possibility of poverty. International economic recession in the 1930s, 1970 s and 1980s reflected the limited power of government in controlling economic forces and contributed to the increasing level of poverty through unemployment, low-wage labour and low pension benefits (Alcock, 2006).

Developing countries are associated with a lack of capability in economic sectors; this is especially true for the low-income, heavily indebted and least developed countries based on the Gross National Income and Human Development Index (World Bank, 2014). Poverty in developing countries is often related to the incapability of the government. Incapable and ignorant governments may even maintain poverty conditions because they do not know how or want to handle the problems of poverty and market failure (Acemoglu and Robinson, 2012). Corruption seems to be a particular problem in developing countries where greedy elites, bureaucrats and politicians enrich themselves by ignoring the societal welfare. Corruption is an obstacle for investment and economic growth; it widens the gap between rich and poor, and it causes losses for human welfare (Justensen and Bjørnskov, 2014). Acemoglu and Robinson (2012) mentioned the example of African countries, where the leaders have created self-enriching economic policies that benefit their own power while their citizens suffer from insecure property rights and economic instability.

Poverty is also the product of a structural hierarchy in social life (Gupta, 2012). Galtung's term of "social violence" explained the concept that a kind of violence can be structured into social, political and economic systems (Galtung, Jacobsen, and Brand-Jacobsen, 2002). This form of violence does not necessarily involve direct or physical violence; it is rather about the exclusion from entitlement such as food, shelter, source of income and social recognition (Gupta, 2012). Because such poverty is embedded in the structure of social, political and 
economic features, the unfortunate condition is not only tolerated but also treated as a normal social phenomenon.

The normalization of poverty is perpetuated not only by the government as the highest decision maker in a country, but also by the distribution of knowledge about how society should perceive the notion of poverty. Poverty is related to the phenomenon of deprivation within a society. Townsend (1987) argued that the standards of deprivation that are created within a society include a lack of primary needs that are otherwise customary and approved in the society, living below the socially accepted standard of living and a lack of participation in society due to lack of resources. When these standards are applied in society, they render some people, especially the poor, unable to achieve established standards of living. People who cannot meet the societal standards or participate in social activities because of their limited resources are described as people who are left out of the society, or as the victims of social exclusion (Spicker, 2007).

Social exclusion is often associated with poverty, as poor people experience discrimination and exclusion in their economic, social, cultural and political lives. Spicker (2007) mentioned there are three types of social exclusion: people who were left out, people who were not protected and people who were pushed out. The marginalization of poor people from society is reflected in how these people are cast as "underclass" people. The notion of the "underclass" developed in the late 1970s and early 1980s in US in order to euphemistically describe the alienation of the ghetto group that lay at the bottom of the societal hierarchy and was excluded from the structural labour market (Lister, 2004). The use of the language surrounding the "underclass" concept in the discussion of poverty has a strong relation with the ideas of stigma and stereotype (Lister, 2004; Spicker, 2007). The terms "poor" and "underclass" carry the power to divide society into different contrasting groups of "poor and rich" or "us and them" (Riggins, 1997). The language itself is not a neutral line, but one that passes a negative value judgement on the impoverished; the language construct the stigma of poverty and gives poor people a negative connotation, thus perpetuating social exclusion. 
The notion of treating the poor as "other" or "them" is part of exclusion that has been popularized by media and constructed in societal behaviour. Structural labelling or stereotyping of poor people determines how other citizens see them and how the poor people see themselves; often, the perception is that poor people sit at the bottom of a social rank. Stigmatization and stereotype is contributing factor for discrediting and dehumanizing the poor (Lister, 2004). People who are born into poor conditions are placed at a low status that leads to social exclusion, and people who are at a higher rank but fall into poverty are judged as suffering from a "moral failing" (Spicker, 2007, p. 71).

The repetitive use of negative labelling to perpetuate the exclusion of poor people could lead to the normalization of discriminative behaviours within social life. Discrimination and stereotyping directed at the poor could have damaging implications for identity and self-esteem (Rimstead, 1997). The undermining of humans' dignity, shame and humiliation are parts of the destructive impact of stigma and stereotype. Humiliation, shame and loss of self-esteem play important roles in shaping identity and maintaining inequality and social hierarchy (Lister, 2004). Poor people experience shame and humiliation in response to the discriminative treatment of society and to their alienation from the social hierarchy, labour market and political participation.

The response to that shame and humiliation may vary from individual to individual; responses may range from passive to aggressive responses. The lack of respect and dignity that poverty imagery generates may lead to anger and frustration (Narayan-Parker, 2000). The desire to fulfil the basic human needs and the desire for respect and human dignity among excluded people are undermined by the reality of the negative stigma and their social exclusion from the society. The contradiction between expectation and reality is a significant element of the frustration and grievances of the poor. The failure to achieve desires, social standards, expectations and rights are likely to produce a sense of deprivation, disappointment and injustice (Merton and Kitt, 1950 cited in Jacoby, 2008). The sense of deprivation among the poor commonly appears in the condition when the 
poor do not meet the social standards of living and when they are excluded from social, economic, and political activities.

The frustration and grievances brought about by unjust treatment regarding the poor tend to manifest in one of two forms: apathy or aggression (Jacoby, 2008). The dynamic responses toward deprivation and frustration depend on the level of individual or collective deprivation. Morrison (1971 cited in Jacoby, 2008, p. 106) explained that the relation between the pursuit of a personal goal and the belief it will not be fulfilled leads to a psychological attempt to reduce the tension, so it is more likely to lower the expectation and choose the action of withdrawal and apathy. In the absence of any alternative options to pursue economic, social or political goals, poor people will feel their sense of helplessness deepen; in parallel, according to Morrison (1971 cited in Jacoby, 2008, p. 106), they will reduce their tension and aggression. However, the hypothesis of the ability of the individual to defuse the tension and aggression may vary from one individual to another. Individuals have different levels of tolerance when it comes to handling and coping with frustration, and the action of withdrawal and apathy could merely be the beginning phase of further accumulation of frustration that, eventually, could explode when the person reaches his limit (Gurney and Tierney, 1982).

The second response to frustration and deprivation is aggression. During social interaction, people may find other people who share the same grievances (e.g. a group of economically deprived individuals). From this interaction, the people move to the building of a collective consciousness of similar or collective resentment, and they begin to confirm a sense of being unjustly treated by the same oppressor (Jacoby, 2008). The psychological bond among individuals within the group members is essential to establishing the identity group as a grievancebased group, as this bond intensifies the sense of deprivation (Moore and Jaggers, 1990). The failure of peaceful means, or the absence of alternative ways to meet the expectations, leads the group to channel their frustration in an aggressive and violent way in order to challenge the status quo or instigate the idea of revolution. 
The status quo is often a condition of stagnancy for poor people, ensuring that they will stay poor; violent action, however, at the very least offers a possibility of future prospects or new opportunities. Rising expectations about future possibilities, loss of legitimacy of the existing social order and frustration with the status quo condition may lead to revolutions (Stewart and FitzGerald, 2001; Jacoby, 2008). The mobilization of individual group members relies on the communication of the common goals, namely to alleviate the deprivation and grievances; to initiate collective action to use violence to compete with other groups (including the state); and to increase the expectation of gain (Jacoby, 2008). Given that the accumulation of frustration with the lack of economic resources and the social exclusion is the fuel for revolutions, material and social improvement are the goals of such revolutions (Jacoby, 2008). Group members' willingness to participate in the violence depends on the potential for it to yield improvement or, in other words, the potential for the action to take the members from having nothing to having something.

Violence can offer the opportunity to gain not only economical resources, but also status and power (Goodhand, 2003). Both acts of violence, such as looting, and supporting armed groups by, for example, participating in illegal trading, can offer poor people access to economic resources (Grossman, 2002). Regardless of the individual costs of injury, imprisonment, and death, poor people participate in violent actions because they generally have "a comparative advantage as they have less to lose" (Goodhand, 2003; Justino, 2009). Violence also serves as a psychological incentive for poor people. The social exclusion, marginalization and humiliation, fuelled by grievances, ignite the violence as a tool to restore dignity, status and power (Keen, 1998). The conflict situation can offer the poor people new status as combatants, fighters or even leaders, while in peace time they are unable hold any high rank of employment (Goodhand, 2003). Fear of unemployment in the status quo makes joining the violent conflict as a combatant a sort of alternative career path; as Keen (1998) stated, "a chronic shortage of employment opportunities has been matched by a contraction in 
educational opportunities and in these circumstances many youths have turned to rebellion as a kind of 'short cut' to wealth as well as status".

\section{Economic Deprivation, Exclusion, Grievances and Violence in West Papua}

Known for its rich natural resources, such as copper, gold and logs, as well as for its high poverty rates, Papua is one of the largest islands in Indonesia. It is divided into two administrative regions, namely Papua or Irian Jaya and West Papua. People in the Papua region, especially the indigenous people, are deprived of access to economic resources, employment opportunities, education and social participation. The Indonesia National Statistics Bureau recorded that in 2014, Papua and West Papua have highest percentages of people living below poverty line, at $27.80 \%$ and $26.26 \%$ respectively (BPS, 2014). This deprivation has triggered grievances among Papuans and created friction and conflict between Indonesia's national army, migrant people and multinational companies operating in Papua.

The Indonesian government, under President Soeharto's regime, encouraged the transmigration programme to increase the economic development all across Indonesia. From the 1970s to 2000, Indonesia's Transmigration Programme was one of the largest resettlement programmes in the world. Poor Indonesian families from overpopulated islands such as Java, Madura and Bali were resettled to the less populated islands, such as Kalimantan, Sulawesi and Papua (World Bank, 2012; Trajano, 2010). Transmigration was used for socioeconomic reasons, in an effort to distribute economic development across less dense regions and to catalyse cultural assimilation in order to create one identity of Indonesia (Budiardjo and Liong, 1988). However, the programme has been criticized as an attempt to marginalize the indigenous Papuans and as the source of the economic deprivation and grievances of the Papuans.

The government of Indonesia sponsored the resettlement of migrant people in part to open the land and forest for agricultural purposes. However, Indonesia's government failed to acknowledge the important economic and cultural values that were attached to the land and forest for the indigenous people. The structural failure that the government enacted led to economic deprivation for the Papuans. 
Land and forest have important economic and religious meaning for them. Papuans view the forest as a source of food, shelter, sanctuary and ancestral sacred ground (Trajano, 2010). Transmigration has forced the Papuans to abandon their ancestral land and, in effect, to abandon the central resource of their lives. A growing per cent of the migrant population, due to the discriminatory regulation of the Indonesian government, has become submerged into poverty conditions. Separated from their natural environment, they are now cut off from their means of production.

Indonesian migrant people dominate the labour market in West Papua. Poor education infrastructure has caused a low education background and minimal work experience among indigenous Papuans. This has resulted in the exclusion of Papuans from the employment market, both in public and private sectors (Manning and Rumbiak, 1991). The state-supported transmigration programmes generated the deprivation and exclusion of Papuans in their own homeland. The assimilation to the Indonesian culture has also contributed to the marginalization of Papuans. Indonesia has many different cultures in every region, but the assimilation policy tends to create one national identity: Indonesian. Papuans are expected to act like migrant people, but this behaviour has only created a social hierarchy within the social life, in which the social values have placed Papuans below the migrants (Trajano, 2010)

One of the features of Indonesia's government under the Soeharto regime from 1966 to 1998 was a high flow economy due to foreign investment. West Papua has rich natural resources, such as gold, copper, oil and gas, as well as strong forestry and fishery industries (BPS, 2014). However, during the period noted, oil and natural gas reserves in West Papua were exploited by British Petroleum, and gold and copper were exploited by the US-based company Freeport Macmoran (The Guardian, 2005; Scott and Tebay, 2006). The investment schemes between the Indonesian central government in Jakarta and the foreign companies were established with no consultation with the local environment and people. Freeport Macmoran, which signed an exploration and exploitation contract with the Indonesian government in 1967, was the largest 
taxpayer to the Indonesian state from 1992 to 2009, paying \$9.3 billion to Jakarta during this period; however, Freeport Macmoran has no obligation to pay compensation to the local people for environmental degradation, social exclusion and poverty conditions (The Jakarta Post, 2010). The economic condition of the Papuans can only be described as dire. The marginalization has been deepened by the foreign companies, which tend to hire migrant workers from other parts of Indonesia or foreigners who have better skills and education than the Papuans. Papuans are excluded from their own economic resources and livelihoods, labour markets and social lives in their own homeland; thus they are held below the poverty line (Scott and Tebay, 2006). The exploration and exploitation of Papua's natural resources benefit the foreign company, the Indonesian government, and the migrant workers, but the Papuans are excluded.

The grievances of the Papuans have led them to conduct violent actions and to join a separatist movement named Organisasi Papua Merdeka (OPM), which translates to the Papua Freedom Organisation. The failure to find peaceful means of settling the deprivation and grievances has made the use of violence the only possible option that the Papuans can see to improve their dire circumstances (Webb-Gannon, 2014). Many complaints have been directed at the mining company, and the Papuans have filed several lawsuits against the company; they have had little to no success (The Jakarta Post, 2010). Special autonomy for the region was granted in 2000 by the Indonesian government to include the Papuans in political aspects; this special autonomy policy gives the right of selfdetermination to the Papuans (Scott and Tebay, 2006). However, the implementation of this policy is far from accommodating Papuans' interest. The mining companies instead began hiring security guards from the Indonesian army to secure the mining sites from the local "illegal" miners. Freeport Macmorans Grasberg mine received special treatment from the Suharto regime and has since become a symbol of Jakarta's discriminative action regarding the well-being of local people. The military support from the Indonesian government aimed to secure the interests of foreign capital and national revenues and to suppress the 
separatist movement. Freeport's mining site has become one of the most militarized sectors in this country (Asia Pacific Foundation of Canada, 2006).

The deprivation and grievances of the Papuans are the results of the inequality and discrimination in income, employment, social treatment and cultural oppression enacted by the Indonesian government and foreign companies. This deprived condition can easily inspire the mobilization of violent movements in order to rise the expectation of future welfare (Goodhand, 2003). From 2009 to 2013, several attacks occurred near Freeport's mining site, targeting not only the security guards, but also the Indonesian and foreign miners (AlJazeera, 2009; Suara Pembaruan, 2013). The violent actions targeted those associated with the cause of the economic deprivation suffered by the Papuans. The Papuan people have been waiting to have their voice heard and to have respect for their most basic of rights. If the Indonesian government does not change its policy to improve the quality of life, alleviate the poverty conditions and eliminate the discriminative regulations against Papuans, the conflict will escalate, and more people will be more likely to join the violent movement to seek improvement of the status quo.

\section{Seeking For Solutions}

Complexity of conflict in West Papua seeks for complex analysis of government policies to solve the problems. The policies could be ranged from conflict resolution to poverty alleviation policies. Inequality and discrimination in economic earning, employment opportunities, social relations, and cultural insensitive in this area need comprehensive treatments to tackle each issues. Seeking the right panacea to treat the crisis is by seeing the violent conflict happened in this region beyond the current phenomena. Analysis on the bases of security approach would not be sufficient since the nature of conflict in West Papua intertwined with development problem, and cultural matter. Government of Indonesia should be capable of taking pre-emptive actions rather than creating solution after the crisis grew bigger.

After the reformation of government, Indonesia was experimenting on decentralisation of politics. Thirty two years of government centralisation which 
limited the opportunities and power of regional government to draft provincial regulation and to develop their own resources. Thus decentralisation was something that done by default as result of the changing of political situation that demand central government to give more autonomy to regional government. Inequality of economic condition and welfare distribution of Jakarta compared to other regions triggered political turbulence in the regions. To handle the situation, Indonesia government created set of regulations Law No. 22 (1999) about decentralisation (updated and replaced by Law No. 32 (2004)) and Law No. 25 (1999) about regional budgeting in local government level (updated and replaced by Law No. 33 (2004)) (Martanto, 2007). The Laws regulate the autonomy of every region to have accountable public services, high social participation, transparency and responsive bureaucracy.

Decentralisation was aimed to boost the regional governments adopting the new concept of good governance in which regional government provide political and economic canals for its people (Jutting et al, 2004). Political canal offered freedom for people to participate in decision making process regarding their economic and social welfare. Economic canal in decentralisation help people in accessing their basic needs such as food, water, housing, electricity, health care and education. In 2001 the central government of Indonesia released regulation which granted Papua with special autonomous region as stated in government regulation / Law No. 21 (2001). This special autonomous regulation was reflection of ideal normative ideas for self-determination of Papuan people and as response to independence movement of West Papua to disintegrate with Indonesia.

Decentralisation was meant to counter the problem of social exclusion of Papuan people. People in Papua were left out and marginalized by social and political system. Participation in local level of government were low. Decentralisation should not only cover the power relations in politics and economic realm, but also should include the concept of multicultural as the bases for the social policies (Paskarina, 2007). The possibility of upholding the speciality of each regions were wide open. And the idea of multiculturalism is not 
only favouring one culture over another, but on how the social system could recognise and accommodate every diversity. Mookherjee (2008) stated that recognition of the inclusion of minorities in decision making process and in social system would help to overcome the prejudice or discrimination.

Multicultural perspective should be considered as one of approaches to overcome the problem in West Papua. Economic deprivation in Papua was assumed to be the result of cultural discrimination towards indigenous people and lead to violent conflict. Recognition to the value of multiculturalism and pluralism would help the government to include the respect towards set of rights of different communities (Mookherjee, 2008). During the New Order socio-cultural was directed into integration and assimilation forms in which culture of the nation referred to the Java as the majority of community. Decentralisation with multicultural perspective give local politics to be space for recognition of uniqueness of the indigenous society (Paskarina, 2007). Local politics recognized the difference of social, economics, culture, politics and identities of local people compared to the national identity. Special autonomous region status gave protection to the indigenous people to develop the economic and political participation without neglecting the local norm values and culture. This protection aimed to give chance for indigenous people empowering themselves and in the end can alleviate the poverty condition in this region. Government regulation as describe in Law No. 21 (2001) stated that Papua province would get biggest of revenue sharing on the natural resources exploration compared to other regions (Muttaqin, 2013).

Philosophically, special autonomous region in Papua was a conflict resolution mechanism from central government to reduce conflict escalation in this area. Hence, social gap and poverty rate are still high after the implementation of the autonomous regulation. Muttaqin (2013) highlighted the transparency in term of power and budget distribution, inconsistency of central and local government, conflict of interest among the Papua elites. Different interpretation of law between central government of Indonesia and local government in Papua creating stagnancy in the customary right of Papua people in managing their land 
and forest for economic development purpose (Kayoi, et. all, 2006). The vacuum of development among Papua indigenous community extended the social unrest and instability in this region. Failure to settle the people's unrest started the discouraging the sustainable investment for economic development and resources management. The burden of decentralised government of Papua was on how to increase the social welfare of its people and creating secure environment for investment the economic cycle.

Alternative solution was needed to seek for effective implementation of decentralisation. Wider opportunity of local participation in social, politics and economic aspect should be taken by local people as a mean to advocate the people aspirations. Strengthening the civil society organisation as representative of Papua people should be more active to guide the supervision of human rights protection, democratic accountability, flow of budget for people-purposed agenda. Gerstbauer (2005) suggested that civil society organisations can be watchdogs for government and monitor the accountability and also function as influencers to government to influence certain issues, in this case poverty alleviation, customary rights for indigenous people of Papua. In Jayawijaya 2004 to 2005, civil society organisations act as political channel for society to protect their social, economic, cultural rights and land customary (Kayoi, et. all, 2006). By encouraging the movement of civil society organisations, it is coherent with the spirit of government decentralisation in which local participation is one of requirement of their government scheme.

Civil society organisation also can be the agent for conflict resolution for the crisis in West Papua. The representative organisations in grass-roots level could have important role in establishing internal rules for conflict resolution on the bases of traditional customary norms and values. Mediation between the local communities, government and private sectors in arranging local based-sets of regulation is also needed to be managed and advocated by civil society organisations. Ensuring the community-based rules implemented for the sake of economic development of local communities. The establishment of Papuan Civil Society Support Foundation (PCSSF) in 2006 was a major improvement in 
managing the development matter (Kayoi, et. all, 2006). PCSSF act as mediator in coordinating and channelling government and donor investment in local economic development.

The success of decentralization requires the sustainability of support and coordination between central government, local/provincial government, and the civil society organisations. The effectivity of the autonomous regulation depends on the continuity of supervision from grass-root organisations. Wider scope for civil society organisation to participate in conflict resolution and economic development will also increase the awareness of people participation to determine their own life. Efforts to increase the transparency and accountability of government through civil society organisation pressure was important to ensure the effectivity of decentralization in reducing poverty and prevent future conflict.

\section{Conclusion}

Poverty is one of the factors that may contribute to violent conflict through its construction of inequality, deprivation and exclusion. State violence, which contributes to the emergence and sustainment of poverty, is a source of structural injustice. The sense of injustice emerges from the growing discrepancy between the conditions the people expect and what they can get. Deprivation concerns not only the inequality of income among people, but also the social discrimination and exclusion of the poor.

The shift from suffering grievances regarding deprivation toward acting out violent movements occurs when the state and other citizens continue to conduct social exclusion toward poor people. The existence of the common demand for improvement of the quality of life is important to gaining societal participation in a violent movement. Poverty conditions make the victims more vulnerable to being provoked into committing violent actions; this vulnerability is due to the grievance of deprivation and the incentives that the violence offers given the misery of the present condition. The violent conflict in West Papua, Indonesia has shown the pattern that state violence can produce and sustain poverty. Unequal standards of living, limited employment opportunities and the absence of alternative solutions to alleviate this poverty is more than likely the 
fuel for the Papuan people to join the insurgency movement and conduct violent actions. The incentive of better standards of living, if they were to gain national freedom from Indonesia, helps to justify the violence as a means to achieving a shared goal. Thus comprehensive approaches should be implemented to overcome the violent conflict and prevent the crisis grow bigger.

\section{References}

\section{Books:}

Acemoglu, D. and Robinson, J.A. (2012). Why Nations Fail: the Origins of Power, Prosperity and Poverty. London, United Kingdom: Profile Books.

Alcock, P. (2006). Understanding Poverty: Third Edition. New York, United States: Palgrave Macmillan.

Budiardjo, C. and Liong, L.S. (1988). West Papua: The Obliteration of a People $3^{\text {rd }}$ Edition. London, United Kingdom: TAPOL.

Galtung, J., Jacobsen, C.G. and Brand-Jacobsen, K.F. (2002). Searching for Peace: The Road to TRANSCEND. London, United Kingdom: Pluto Press.

Gerstbauer, L.C. (2005). The New Conflict Managers: Peacebuilding, NGOs and State Agendas. In: Krahman, E. ed., 2005. New Threats and New Actors in International Security. New York: Palgrave Macmillan.

Gupta, A. (2012). Red Tape: Bureaucracy, Structural violence, and Poverty in India. Durham, United Kingdom: Duke University Press.

Jacoby, T. (2008). Understanding Conflict and Violence: Theoretical and Interdisciplinary Approaches. Oxon, United Kingdom: Routledge.

Jutting, J, et al. (2004). Decentralisation and Poverty in Developing Countries: Exploring the Impact. Paris: OECD Development Centre Working Paper 236.

Lister, R. (2004). Poverty. Cambridge, United Kingdom: Polity Press.

MacGregor, S. (1981). The Politics of Poverty. London, United Kingdom: Longman.

Manning, C. and Rumbiak, M. (1991). "Irian Jaya: Economic Change, Migrants, and Indigenous Welfare". In H. Hill (Eds), Unity and Diversity, Regional Economic Development in Indonesia since 1970. Singapore: Oxford University Press.

Mookherjee, M. (2008). Multiculturalism. In C. McKinnon (Eds), Issues is Political Theory. Oxford: Oxford University Press.

Narayan-Parker, D. (2000). Can Anyone Hear Us? . Oxford, United Kingdom: Oxford University Press for World Bank. 
Novak, T. (1988). Poverty and the State: An Historical Sociology. Milton Keynes, United Kingdom: Open University Press.

Riggins, S.H. (1997). The Rhetoric of Othering. In S.H. Riggins (Eds.), The Language and Politics of Exclusion (chapter 1). Thousand Oaks, Calif.: Sage.

Rimstead, R. (1997). Subverting Poor Me: Negative Construction of Identity in Poor and Working Class Women's Biographies. In S.H. Riggins (Eds.), The Language and Politics of Exclusion (chapter 11). Thousand Oaks, Calif.: Sage.

Spicker, P. (2007). The Idea of Poverty. Bristol, United Kingdom: Policy Press.

Stewart, F. and FitzGerald, V. (2001). Introduction: Assessing the Economic Costs of War. In F. Stewart, V. FitzGerald, and Associates (Eds.), War and Underdevelopment Volume 1: The Economic and Social Consequences of Conflict (chapter 1). Oxford, United Kingdom: Oxford University Press.

Journals:

Goodhand, J. (2003). Enduring Disorder and Persistent Poverty: A Review of the Linkages between War and Chronic Poverty. World Development, 31(3), pp. 629-646. http://www.sciencedirect.com/science/article/pii/S0305750X0300009 3\#

Grossman, Herschel I. (2002). "Make Us a King": Anarchy, Predation, and the State. European Journal of Political Economy, 18(1), pp. 31-46. http://www.sciencedirect.com/science/article/pii/S0176268001000672

Gurney, J.N., and Tierney, K.J. (1982). Relative Deprivation and Social Movements: A Critical Look at Twenty Years of Theory and Research. The Sociological Quarterly, 23(1), pp. 33-47. http://www.jstor.org/stable/4106351

Justensen, M.K. and Bjørnskov, C. (2014). Exploiting the Poor: Bureaucratic Corruption and Poverty in Africa. World Development, 58, pp. 106115. http://dx.doi.org/10.1016/j.worlddev.2014.01.002

Justino, P. (2009). Poverty and Violent Conflict: A Micro-Level Perspective on the Causes and Duration of Warefare. Journal of Peace Research, 46(3), pp.315-333. http://jpr.sagepub.com/content/46/3/315.full.pdf+html

Martanto, U. (2007). Kemiskinan di Indonesia: Potret Buram Desentralisasi. Jurnal Mandatory: Politik Kesejahteraan di Tanah Republik, 3(3), pp. 45-58. Yogyakarta: Institute for Research and Empowerment.

Moore, W. and Jaggers, K. (1990). Deprivation, Mobilization and the State: A Synthetic Model of Rebellion. Journal of Developing Societies, 6(1), 
pp.17-36.

https://whmooredotnet.files.wordpress.com/2014/07/deprivationmobilization.pdf

Muttaqin, A. (2013). Otonomi Khusus Papua Sebuah Upaya Merespon Konflik dan Aspirasi Kemerdekaan Papua. POLITIKA: Jurnal Ilmu Politik $4(1)$, pp. 5-18. http://ejournal.undip.ac.id/index.php/politika/article/view/6064

Paskarina, C. (2007). Multikulturalisme dalam Memahami Dinamika Politik Lokal: Pendekatan Alternatif di dalam Perumusan Kebijakan Publik. Jurnal Mandatory: Politik Kesejahteraan di Tanah Republik, 3(3), pp. 45-58. Yogyakarta: Institute for Research and Empowerment.

Scott, C. and Tebay, N. (2005). The West Papua Conflict and Its Consequences for the Island of New Guinea: Root Causes and the Campaign for Papua, Land of Peace. The Round Table: The Commonwealth Journal of International Affairs, 94(382), pp. 599-612. http://dx.doi.org/10.1080/00358530500331826

Townsend. (1987). Deprivation. Journal of Social Policy, 16(2), pp 125-146. http://dx.doi.org/10.1017/S0047279400020341

Trajano, J.C.I. (2010). Ethnic Nationalism and Separatism in West Papua, Indonesia. Journal of Peace, Conflict and Development, 16, pp. 12$35 . \quad$ http://www.bradford.ac.uk/ssis/peace-conflict-anddevelopment/issue-16/etthnicpapua.pdf

Webb-Gannon, C. (2014). Merdeka in West Papua: Peace, Justice and Political Independence. Anthropologica, 56(2), pp. 353-367. http://muse.jhu.edu/journals/anthropologica/v056/56.2.webbgannon.pdf

\section{Online Sources:}

AlJazeera. (2009). Papua Attacks Blamed on Separatists. 13 July 2009. Accessed on 4 May 2015. http://www.aljazeera.com/news/asiapacific/2009/07/200971343448282245.html

Suara Pembaruan. (2013). Penembakan di Areal PT Freeport, Sopir Kena Serpihan. 28 Desember 2013. Accessed on 4 May 2015. http://sp.beritasatu.com/home/penembakan-di-areal-pt-freeport-sopirkena-serpihan/47157

The Guardian. (2005). Papua Action. 5 May 2005. Accessed on 4 May 2015. http://www.theguardian.com/business/2005/may/05/oil.indonesia

The Jakarta Post. (2010). Resource-rich West Papua, but Who Benefits? 14 May 2010. Accessed on 4 May 2015 http://www.thejakartapost.com/news/2010/05/14/resourcerich-westpapua-who-benefits.html 


\section{Global Insigint Journal}

\section{Report:}

Asia Pacific Foundation of Canada. (8 March 2006). Freeport's Conflict in West Papua Highlights Troubles for Indonesian Miners. Asia Pacific Bulletin.

http://www.asiapacific.ca/sites/default/files/archived_pdf/apbn/bulleti n249.pdf

BPS (Badan Pusat Statistik). (2014). Statistik Indonesia: Statistical Yearbook of Indonesia

http://www.bps.go.id/index.php/publikasi/326\#accordion-daftarsubjek3

Kayoi, M. et al. (2006). Poverty and Natural Resource Conflict in Indonesian

Papua: Reconciling Growth and Social Justice.

http://www.profor.info/Documents/pdf/livelihoods/IndonesianPapuaC aseStudy.pdf

UN (United Nations). (1995). World Summit for Social Development Copenhagen, 1995. http://www.un.org/esa/socdev/wssd/text-version/

World Bank. (2012). Transmigration in Indonesia. http://lnweb90.worldbank.org/oed/oeddoclib.nsf/DocUNIDViewForJa vaSearch/4B8B0E01445D8351852567F5005D87B8

World Bank. (2014). Update Income Classifications. http://data.worldbank.org/news/2015-country-classifications 